\title{
Closed circles of mistrust: envy, aspirations and urban sociality in coastal Madagascar
}

\author{
Patrick Desplat
}

\section{Introduction}

In 2014, I met with Luc for an evening beer in one of the bars around Bazary Be, the 'big market' in the port quarter of Mahajanga, a city in north-western Madagascar. Luc, aged twenty-eight, was an English teacher and worked at the university as a civil servant for logistics in one of the newly established departments. Since I had met him several years before, he had searched persistently for ways 'out' and to go abroad, never intimidated by failed attempts, unfulfilled promises or unreliable contacts. After some drinks and the usual chit-chat, Luc announced his new strategy: to leave the country with the help of a yet unknown female from the United States who would arrive with a tourist group in the upcoming weeks. The Malagasy tourist organizer had asked Luc to help out as a translator due to his proficiency in English. As a successful womanizer, he was confident of his chances of seducing one of the women and dreamed about marriage and the necessary papers to leave the island. I asked him how he would explain this scheme to his girlfriend Carolle and if he ever discussed his new strategy with his friends. After a long look of disbelief, he responded: 'Telling my friends? Telling Carolle? No, never! They would kill me out of envy!' Followed by the request not to talk to anybody about his plans, he continued explaining issues of deep mutual mistrust within urban society, unlike in one's relationship with one's most intimate family members.

During my fieldwork on migratory projects among young students and graduates in the port city of Mahajanga, I often heard similar disturbing stories concerning other people's envy. In their search for a better life and fulfilment of their ambitions, Luc and other young educated urbanites worried that envious peers would resent them for any advantage they might have gained, and that they would harm them, damage or destroy their possessions or poison their life in general. In everyday life, kindness in interactions with others was met with great doubt, and open curiosity with the utmost suspicion. Suspected of having hidden intentions, they were answered by acts of indirectness, denial and joking, and more often by silence; these were polite responses that could signal avoidance of a sensitive topic as well as disagreement and dissociation. As an idiom, the envy of others is used by young urbanites to justify tactical practices of secrecy that should help to secure an individual's well-being and shield them from unsocial behaviour. As a discourse, the fear of others' envy ran so deep through the

Patrick Desplat is a postdoctoral research fellow with the Forum for Interdisciplinary Religious Studies at the University of Göttingen. He has published widely on Muslims in Ethiopia and currently researches (failed) migratory projects of young men from middle-class milieus in Madagascar. Email: pdespla@uni-goettingen.de 
everyday social fabric that some of my informants linked their expectations of migration to the hope that envy would be less intense outside Madagascar.

At the same time, envy is a highly sensitive topic and neither wholly admitted to by individuals nor discussed in public. In a society such as Madagascar, where status, shame and face-saving play a tremendous role, nobody would admit that they were envious since that would signify an inferior status in relation to others. Any sort of envy would be denied, disguised or relabelled. In addition, nobody would openly accuse someone else of being envious, unless a conflict between the two parties had already escalated. To express a fear of others' envy, on the other hand, is rather common, although many of my informants often used indirect and tacit ways to do so, through narratives, proverbs and fictive situations that kept themselves - as well as other people - outside an explanatory frame. ${ }^{1}$

Envy (fialonana) is one of the key experiences in the everyday life of most young people in Mahajanga and narratives of aspiration are largely structured around expectations of constraints, betrayals and sometimes violence caused by other people. Envy cuts across gender, class and age, as well as ethnic and religious relations, and its social expressions differ in many ways.

The most striking revelation that could be heard in widespread narratives was that the danger of malicious envy lurks in close relationships; usually, your best friend is expected to be the person who will drag you down. Who can you trust when close companions can betray and harm you? How does the fear of a close other's envy inform - and be informed by - social practices of secrecy and openness, visibility and invisibility, public and private spaces?

This article envisions the ubiquitous envy-related discourse as a window through which to understand the diverse ways in which young students and university graduates in Mahajanga imagine, experience and engage in urban interpersonal relationships. It analyses how these young, educated people struggle to fulfil aspirations that are inspired by their middle-class milieus and to cope with the challenges that any future enhancement in their status would pose in relation to socially close peers who are less successful. I examine the micro-politics of life projects in which social comparison, increasing inequality and a rising sense of mutual mistrust exist in social situations fraught with tension.

Analytically, envy shares a triangular structure with jealousy. It contains the envied, the envier, and an object of desire. However, they are conceptually different: jealousy is a protective reaction towards an object that one possesses and that is in danger of being lost, while envy is a feeling of hostility towards a perceived superior or someone who is better off. The object, here the success of the other, acquires a rather secondary meaning (Clanton 2006). Envy affects - and is affected by - broader social structures, cultural concepts and political economies. In anthropology, as in many other disciplines, envy has been treated as either

\footnotetext{
${ }^{1}$ This has been a very common phenomenon. At the same time, several of the students and graduates whom I came to know over several months gradually opened up in discussions surrounding envy and provided the main empirical data that I present here. In total, I interviewed forty-two people, mostly students and graduates, but also their parents and university teachers. As a teacher giving courses at the university in Mahajanga, I had good access to many students, whom I interviewed mainly in private settings including their student dorms and cafés, and exclusively with male students - during the evenings in local bars.
} 
constructive or destructive (see Cohen-Charash and Larson 2017; Schoeck 1969). Probably the most prominent and theoretically founded approach to envy originated in early Marxist-inspired peasant studies in Latin America. Taking envy as a basic human condition, Eric Wolf, for instance, understood 'institutionalized envy' as a psychological mechanism of control that restrains non-conforming behaviour and maintains individuals in equilibrium with their fellow human beings (Wolf 1955: 460). Similarly, George Foster (1972) argued that worldly goods are limited and thus the success of one person is perceived as being obtained at the cost of others. The fear of others' envy thus leads to a refusal of accumulation and explains the lack of interest in achieving new prospects. The basic norm is that people all feel equal to one another, and that group interests supersede individual accumulation, resulting in group stability but also economic stagnation. Foster's analysis of envy is ultimately the peasant's rationale of security and isolation, a zero-sum approach in which belonging and stability are more important than individual success. ${ }^{2}$

Studies on the evil eye and witchcraft, on the other hand, highlight the dynamic relations of blame and violence, as well as political economies, and unearth the social realities underlying beliefs in the occult. However, these important scholarly debates rarely conceptualize envy beyond its emotional aspects as the primary motivational factor for witches, or as being directed towards those who are materially better off, comparing it with feelings of jealousy, resentment and greed. Importantly, the core arguments of this article do not address witchcraft per se. While these feelings are used to describe the dynamics of individual or familial misfortune, envy-avoidance practices and an increase in mistrust are similarly described in witchcraft studies. Although witchcraft and the associated practices of 'bad medicine' (fanafody ratsy), poison (poizina) and love magic (aody fitia) are widely known as mosavy (Danielli 1947; Ellis 2002; Gueunier 1975; Hardyman 1974), individual or familial fears of envy tend to be related to everyday violence and are framed using narratives of slander and backbiting, stealing or burning goods by fellow neighbours, friends or colleagues.

I would like to depart from these investigations and argue that fear of others' envy in Mahajanga is neither a prosocial levelling mechanism nor a destructive force that destroys social bonds. I question the utility of envy as a tight analytical concept, but see discourses of envy as assemblages that point to intertwined social aspects. Social actors in Mahajanga realize the problematic and constraining nature of envy, and as a consequence they do not refrain from some measure of concealment and disguise. Instead, they try as much as possible to balance and navigate social proximity and distance. The effects of envy are neither constructive nor destructive. Like any other fear, it has to be overcome, and, as I illustrate later, it can even be appreciated as a driving force or an achievement and can improve social standing.

Narratives of those who fear others' envy are articulated by the better-off in relation to those they consider to be developing unsocial behaviour that might harm their attempts at social mobility. Middle-class milieus are particularly

\footnotetext{
${ }^{2}$ This approach to envy has prevailed until the present in Latin American studies, while broadening the initial perspective on oral cultures (Taggart 2012), inter-ethnic relations (de Vidas 2007), migratory contexts (Tapias and Escandell 2011), potters in villages (Castellanos 2013) or urban contexts (Hicks 2013).
} 
vulnerable to such discourses. What makes envy so prominent among members of the middle classes are their expectations for the future, and particularly their anxieties about any loss of status. Their daily struggle and worries about 'keeping up with the Joneses' - in this case their friends, neighbours and colleagues - failed promises and the perception of being stuck are central issues in middle-class self-definitions. Whenever they engage in so-called life projects, such as migration or decisions connected to their professional lives, envy-related discourses are particularly prominent. Through scrutinizing envy as a specific anxiety relating to aspiration, I therefore offer a complementary perspective to recent scholarship on the middle classes in Africa (Behrends and Lentz 2012; Kracker Selzer and Heller 2010; Mercer 2014; Southall 2004; Spronk 2012; Sumich 2015; West 2002).

Envy discourses in Mahajanga, however, are less about experienced harm than about expectations and general suspicions concerning the hidden intentions of other people. Mistrust not only emerges due to increasing competition among young people but is rooted in a normative code of conduct that promotes the avoidance of conflict and indirectness in speech (Freeman 2013; Keenan 1974). My aim is not to depart completely from the prominent view that Malagasy society is built upon forms of social cohesion, mutual love and the 'vision of a peaceful society' (Kneitz 2014a). By looking at young people's perceptions of and constraints within the everyday urban sociality of Mahajanga, I understand envy as a 'negative-unifying principle', to use Kierkegaard's term, binding people who are already close into an even tighter web of tension. Young people in Mahajanga, as the phrase goes, keep their friends close but their (potential) enemies closer. This closeness strengthens, maintains and confirms the normativity of social cohesion.

\section{Fihavanana and the foundation of envy in Madagascar}

Scholarly accounts of Madagascar display a robust imbalance between a widespread and openly articulated normative code of relatedness that pronounces, on the one hand, solidarity, trust or mutual kindness as core elements of Malagasy culture, and, on the other, conflictual issues and an often unspoken 'darker' social undercurrent of envy and resentment. For several decades, norms and values that promote solidarity and compassion towards others have been discussed and explained through the Malagasy concept of fihavanana (Dahl 1999; Dez 1981; Kneitz 2014b; Njara 1992; Sandron 2008; Wallner 2016), a term that roughly translates as friendship, kinship or mutual goodwill. Fihavanana is rooted in a broader conception whereby individual agency is generally suspect, and thus it promotes the collective projects of a solidary moral group. Fihavanana derives from havana, roughly translatable as kin. Paul Ottino defines havana as a moral term that describes a 'relational quality of reciprocal trust that is characteristic of relations between kin or co-residents in the same locality' (Ottino 1998: 280; my translation from French). Basically, havana is a highly inclusive social as well as moral category that might incorporate consanguine and affine relationships, but is often used to address anybody with whom one is related through blood, work or friendship, including the ancestors. Maurice Bloch ascribes the highest moral value to havana, equating it to a general sense 
of deep trust, and states that its evocation in any public speech expresses the duty of mutual love, conflict avoidance and cooperation (Bloch 1971: 59). ${ }^{3}$

Fihavanana tries to broaden the issue of mutual trust from a restricted microlevel encompassing all Malagasy under the fihavanana gasy. As such, it was critically discussed by my young, educated informants. ${ }^{4}$ Most argued that fihavanana is a concept of the past or that it is associated with images of a rural, traditional life. At the same time, most young Mahajangais feel constrained by the concept as it implies obligations of sharing and reciprocity that they cannot or do not want to fulfil. Rather than being ascribed by others as havana, they want to choose themselves who should be havana and who should not be. By distancing themselves from others, envy is often brought into play to justify their dissociation.

Their perspectives are congruent with those noted in other anthropological studies that focus on conflict in Malagasy societies. David Graeber (2007), however, has been the only anthropologist on Madagascar so far to devote attention to envy. His ethnography on politics and history draws the reader into the world of Betafo, a village in the central highlands where magic and the legacy of slavery are strongly intertwined. The inhabitants of Betafo seem to be constantly circulating and manipulating impressions of secret powers, but they do so without violating the norms of non-confrontation and without giving rise to rumours that might endanger their standing in the community. For Graeber (ibid.: 212), envy is the 'archetypical Malagasy vice'. Despite an ethos of equality, mutual love and sharing - an ethos that predominates in social science perspectives on Madagascar - Graeber notes that he:

heard a great deal about envy. Of all the hidden motives and emotions assumed to lie behind ordinary interaction, envy was considered the most dangerous and destructive. When one asked what drove people to bewitch each other, the reply was always automatic: it was because of fialonana, of envy. By this they did not so much mean envy in the sense of covetousness, the desire to acquire some good or advantage because one's neighbour had it, but in the purely destructive sense of wanting to deprive them of it, or harm them in some other way out of resentment. (Graeber 2007: 81)

Subtle rivalries, mutual manipulations and covert aggression led Graeber to classify envy as 'destructive empathy' (Graeber 2007: 85): an envier imagines himself to be in the place of someone who is more successful, but instead of being neutral he develops a grudge against the other person and tries to harm him or her out of feelings of hostility. This resentment leads to practices that are intended to harm the envied person, such as witchcraft, love magic and/or the sexual seduction of his or her partner.

Other ethnographic accounts confirm that envy is a widespread social phenomenon in Madagascar, yet it is often relegated to the footnotes or sidelines of the main argument. Maurice Bloch, for instance, mentioned envy only briefly when

\footnotetext{
${ }^{3}$ At this point, Bloch explained that for the Merina someone who is not havana and therefore not trustful is a 'potential witch' and that people are terrified to eat in their houses out of fear of being poisoned.

${ }^{4}$ Only one older and retired gendarme explained that fihavanana is still in existence. He used the city of Mahajanga as an example, as a place where people from diverse ethnic backgrounds and origins get along harmoniously.
} 
he described that some Merina villagers did not repair their house or that they wore ragged clothes out of fear of others' envy (Bloch 1971: 114). In her book on spirit possession in the coastal town of Ambanja, Leslie Sharp described the evasive behaviour of some informants who were terrified by the neighbours' envy (Sharp 1996: 199), while in a subsequent ethnography on youth, she reported a student being killed out of envy by forceful magic (Sharp 2002: 259). In her work on memory and colonialism, Jennifer Cole briefly stated that her rural informants claimed that envy is a particular 'Betsimisaraka emotion' (Cole 2001: 220), the Betsimisaraka being one of the ethnic groups living on the east coast. Cole argues that envy has its roots in structures of social inequality and urban-rural divisions that were created through French colonial rule. Despite the apparent prominence of envy among her informants, Cole failed to collect more detailed data since her informant 'just laughed uncomfortably and changed the subject' (ibid:: 220).

Although it is difficult to extract a pattern from these remarks, most instances of envy involved magic, gossip and witchcraft - hostilities performed by those who envy - and, in some cases, practices designed to avoid the envy of others through concealment or evasive behaviour. However, probably the most interesting point is that envy is indeed a widespread social phenomenon in Madagascar and that it is not restricted by ethnic or religious affiliation or by rural or urban setting. Envy, as observed by Cole and Graeber, becomes most active in contexts of social transformation in which old hierarchies are questioned and new forms of inequality are likely to appear.

For this article, two basic principles are particularly important. First, envy is related to social comparison. People in Mahajanga constantly assess one another by looking at and gossiping about what others do (or do not) possess, how they live, dress, speak and move through the city. In their evaluation, they compare themselves with others and estimate what possibilities they have for their own future - or what possibilities have been denied to them due to their scare resources or lack of competence. Strictly speaking, the fear of others' envy is a downward comparison, which, according to Festinger (1954), strengthens self-esteem and feelings of superiority. Although most Mahajangais are worried about envy and its consequences, they perceive potential acts of violation as unsocial and unjust. On the other hand, rich people who are suspected of envying someone below them on the social ladder are belittled and their status, education and manners devalued.

Second, it is essential to note that social evaluation works best with people who are socially close. In his paradigmatic account of witchcraft among the Azande, Evans-Pritchard pointed out that envy usually arises in close social relations between those who consider themselves equals (Evans-Pritchard 1976 [1937]: 45), an idea that was developed further in Peter Geschiere's (2003) description of witchcraft as the 'dark side of kinship'. Social proximity in Mahajanga does not necessarily include only the intimate domain of the family; it also embraces those who are of the same age, gender or locality/neighbourhood, or who share a workplace or attend the same educational institution. They are often called havana and addressed as 'brothers' or 'sisters'. In the classic sense, nearness can be spatial, as in a neighbourhood, or social, among friends - or it can refer to a situation where there might be competition, such as university or work. The fear of envy relates to those people who belong to one's own emotional 
environment and have a significance through kin, friendship or as fellow students or colleagues. Envy works as a marker of an ambivalent relatedness and mistrust. Although such people are socially close, even within the definitions of havana, they are suspected of having hidden intentions. On the other hand, they are necessary as part of a wide social network, and so one is forced to trust them at least to some extent. This ambivalence might even encompass members of the household (tokatrano): that is, those who are considered to be the most trustworthy, at least in relation to other household members. ${ }^{5}$

\section{Youth, aspiration and the boundary work of middle classes in Mahajanga}

With its lively and sociable community, its calm and predictable slow rhythm, an animated seaside promenade, vivid nightlife, attractive beaches and warm climate, Mahajanga has become one of the major tourist destinations in Madagascar over the last decades. Visitors and strangers have a long history in the Indian Ocean port city, which has a population of approximately 300,000 people. Mahajanga has been a prime immigrant town, attracting people from throughout the Indian Ocean as well as Malagasy from inland areas. The urban milieu has been able to integrate cultural particularities and has developed, maintained and continuously expanded a remarkable diversity that has been described as intrinsically cosmopolitan (Andriamitantsoa 2009; Ballarin 2006; Lambek 2003).

Despite their rather harmonious coexistence, for which Mahajanga is known throughout Madagascar, most Mahajangais have faced new forms of economic hardship since the internationally condemned coup in 2009. The resulting political and economic instabilities during the transition period, commonly known as la crise, resulted in rising costs for staple foods, a lack of employment and an increase in formerly low levels of criminality, all of which added to already existing difficulties. Since the end of 2013, the democratically elected government has failed to instil optimism; rather, it has created an impression that the situation will get 'worse and worse' (miharatsy miharatsy foana). The present pessimism is well justified, considering what some researchers have termed the 'Malagasy paradox' (Razafindrakoto et al. 2015). According to this view, Madagascar has suffered from a severe cycle of continuous economic downturn that has been fed by a particular pattern: whenever the country witnesses indications of economic growth, political crises inevitably follow, resulting in further economic problems.

However, despite this general pessimism and new forms of competition for the scarce job opportunities and for money, the city of Mahajanga has remained a place of (some) opportunities. Historically, the town's economy has depended on the port and, since colonial times, industrial fishing. At the same time, agricultural production locally and in the nearby region of Mahajanga is strong. In addition, the government provides those job opportunities that most youth strive to obtain:

\footnotetext{
${ }^{5}$ This is, of course, a very relative view. Members of a household struggle with several forms of suspicion and mistrust. For example, cheating is a common problem among couples and results in a particular form of mistrust. Siblings, moreover, tend to compete with one another for the love of their parents, which might cause deep ruptures. If someone among the close family is considered untrustworthy, they are considered a 'weak witch' (mpamosavy malemy).
} 
Mahajanga is the administrative capital of the region of Boeny and therefore hosts the administration of both the commune and the state, in addition to the police, gendarmerie, military, university and state-owned hospitals. Due to the jobs that these institutions provide, the city has a stable middle class and a relatively low number of unemployed as well as a low rate of criminality compared with national statistics. Despite the overall pessimism concerning the future of Madagascar, there is generally hope for individual achievement, in particular among young educated people, who envision and anticipate possible opportunities.

During my fieldwork in Mahajanga, I commonly overheard young people talking about their desire for a 'better life' (fiainana tsaratsara kokoa). Many Mahajangais feel stuck, and one of the most common hopes that young people articulate is 'to be able to get out' (tafavoka, shortened to tafa). In order to transform the common uncertainty into certainty, most young people whom I met expressed two dreams to secure their individual future and that of their families: to leave Madagascar and migrate to Europe, and to get a position within the state civil service. The two dreams are usually joined, in that migration is framed as a stepping stone for obtaining a better position in Madagascar upon one's return. These visions, however, rarely transform into reality, and the widening gap between the desire to change one's life for the better and the existing constraints to doing so leave many young people frustrated with their overall situation. Young women may choose an alternative strategy by searching for European men, who come en masse as tourists or short-term settlers to the island, as described in relation to the east coast of Madagascar by Cole $(2010 ; 2014)$. Young men, on the other hand, are often left doubly frustrated by a shifting economy in which 'their' young women lose interest in Malagasy men while being restricted in their migratory plans. Very few of them are able to activate existing social networks abroad, so they have to fall back on more established patterns of migration such as educational migration, which is beset with bureaucratic hurdles and unequal distribution of scholarships and tends to be time-consuming and costly.

Getting a prestigious job with a state institution is similarly problematic. Governmental jobs are perceived as providing the most security and future stability compared with the private sector, which promises higher financial rewards but where jobs are usually temporary. Although state-related jobs are badly paid, they provide a fixed and steady (low) income, they are typically permanent, the salary is raised periodically according to the level of experience, and, more importantly, they provide a pension after retirement. Apart from offering a more secure setting, these positions provide more informal benefits. They offer new possibilities to build up social networks and connect with influential people, to engage in corruption and to access information and goods. However, these jobs have become extremely rare and it is said that nearly half of publicly advertised posts have already been given to the sons of other civil servants, while the rest are open only to those who pay the most. Realistically, if one wants to enter any level of the civil service, a 'massage' is required - a common metaphor for a bribe. Yet, I met several students who had entered the gendarmerie and therefore dropped out of their studies. Moreover, I heard of desperate cases in which young people worked for free in the administration and lived in hope of being employed officially in the future.

In Sex and Salvation (2010), Cole argues that education became an ineffective strategy for young Malagasy in the eastern port city of Tamatave to reach the 
status of adulthood. The continuous impoverishment of educational institutions, the frustrations of unemployment after graduation and the longing for global consumption result in new goals, role models and creative practices to succeed in life. The new orientation is highly gendered: while young men engage in semi-legal or legal biznesy, business, many young women enter the sex economy to find a European husband.

The situation in Mahajanga is different, at least among students and their families. The city is considered to be less competitive, with a smaller gap between rich and poor, the sex economy is less developed and conspicuous consumption less pronounced. Most of my student informants - and, more importantly, their parents - still considered higher education as a way to a better life. Students and graduates are termed 'knowledgeable' (manam-pahaizana; literally 'specialists of something'), a term that indicates a middle-class background. Their aspirations to join the civil service or migrate are based on the old promises of higher education. Since the 1940s, the migratory patterns for educational training prior to entering the state service have been through metropolitan France. After the establishment of universities in Madagascar, students did not necessarily need to migrate anymore, but a diploma from abroad is valued much more highly than any local qualification, thus facilitating entry into the civil service. Since students continued to flock to universities, at a certain point the state was unable to provide enough jobs for the highly educated masses. Still, the dream of a governmental position persists for most students, and the prestige that is ascribed to being a student is relatively high compared with not being engaged in higher education. Most graduates will find employment - though rarely in jobs that fulfil their dreams - even though the job market might be tight. The longest time that I heard a graduate had taken to get a job was about one year. This does not mean that there are sufficient jobs for all those who desire them, in terms of competence, salary and hours. Underemployment is still a growing problem among youth in Mahajanga

Their status as students from a middle-class background is important in the context of envy because it is this slightly elevated position and the promise of a university diploma that make them possible victims of envy discourses. I once overheard a discussion between two female neighbours in Mahajanga about the future of their daughters who studied in the capital of Antananarivo at the respectable Catholic University. Both daughters, who were close to graduating, planned to continue their education in Europe and both women agreed that they needed 'to be careful' because of the possible envy and resentment of others. This short discussion clarified not only the dangers of status enhancement but also that youth do not aspire to life-changing goals individually. Aspirations are usually supported by the family, are part of family decisions and are motivated in part by the ambitions of parents.

The basis for engaging in migration schemes or in the professional life of a civil servant is rooted in the background of middle-class milieus. Middle-class status in Mahajanga is characterized by a professional position and consumption practices. Frequently, one or two members of the family work in lower-level regional state administration, as policemen or gendarmes, while the remaining members either attend school or are active in the informal sector. The fact that they strive for security in a vulnerable political and economic situation determines many other typical features. Very few families from middle-class milieus engage 
in conspicuous consumption. If investments have to be made, they tend to relate to the acquisition of land and housing and the education of their children. Very few of these families, for example, own a car, although some may own a scooter. Investments in mobile telephones or laptops, on the other hand, are increasing, but these are perceived as necessary items in a world that relies on communication as well as education, for which computers are usually used.

What does 'middle class' mean in Mahajanga? Although the French equivalent, classe moyenne, is rarely mentioned, there is a broad spectrum of local terms that describe different and often overlapping middle-class milieus that engage in continuous boundary work as well as being united in their perception of in-betweenness, sandwiched between the poorer inhabitants and richer social elite groups (Lentz 2015). ${ }^{6}$ As a result of the slightly elevated status of the families described, other Mahajangais from a lower status usually call them fanjakana (literally 'state', a term that highlights power through governmental positions) or economically as 'people who could afford to buy' (olona manana fahefa$m v i d y$ ). At the same time, it is common for these middle-class families to downplay their social status; they would call themselves olonoa tsotra, 'ordinary people'. Although people recognize socio-economic differences, inequalities and class structure in the city, they are highly reluctant to position themselves along hierarchical lines. By calling oneself 'ordinary', one transcends boundaries of difference and related inequalities (Savage et al. 2001). As such, the term echoes a strong egalitarian strain in contemporary Malagasy culture, where virtues such as fihavanana, harmony and mutual respect still prevail as values even if their current implementation in everyday life is denied.

In a positive way, some of these families would consider themselves as olona mahitahita, 'people who see', being open-minded, aspirational, and using social networks and education. 'To see' is not the appropriated knowledge of education, although there is a correlation, but rather an open-mindedness and a broad horizon that provides the potentiality of being successful without necessarily being affluent. Although a certain level of resources plays an important role, 'to see' means to have ambitions, and moreover to have knowledge about the right strategies to fulfil them. This means knowing how to invest one's scarce resources to gain the most in the long term, through higher education or the acquisition of land. It also means being able to build social networks that might be helpful on the way to having a better life. Yet, 'to see' is not to be cunning or even to breach normative boundaries. It is more about the capacity to appropriate new ideas, to profit from old ones and to be able to 'eke out a living' (midebrouiller, from the French débrouiller), a term that is used to describe the activities of people who successfully stand their ground against everyday struggles. However, life projects are uncertain even for middle-class families. In practical terms, they

\footnotetext{
${ }^{6}$ Other typical terms relating to the middle class are mpanankarena tampoka (literally 'suddenly got rich') and arrivistes. People from lower classes are often named sarambambem-bahoaka ('struggling people'), and there are different sub-terms such as vahoka tsy mandady harona (literally 'people who don't crawl on the basket'), mahantra ('poor' or 'afflicted') and maskiny ('little people'). On the other hand, rich people or the elite are called manam-boninahitra ('people with dignity'), with the subgroup mpanan-karena or mpanam-bola, both meaning 'people of wealth' or 'people of money'.
} 
contain a double uncertainty since the outcome is unpredictable and others' envy might block them.

\section{Secrecy and disclosure in narratives of envy}

One of the first stories that I heard from students was one of betrayal and hidden intentions. There were widespread examples of peer learning groups in which some participants pretended not to know the solution to a problem but would 'spy' on others in order to benefit during the upcoming exams; or of students who persuade others in the back row of the classroom to play cards, pretending not to care about the lesson, but who secretly study for exams during the long night hours. These narratives are not explicitly about envy, but reflect the social dynamics of secrecy and the disclosure of knowledge. They centre on the unsocial behaviour and hidden intentions of others who students consider to be merely pretending to be close friends and social. As they explain further, those who pretend take advantages for themselves and harm others in situations of competition - in this case usually exams, the culmination of their rivalry. The expectation of betrayal is prominent and can be found in any social field. These narratives are the blueprint for - and are essential to - similar experiences that focus on envy. The dominant theme is that, at a certain point in a relationship, trust flips over into mistrust. Trusted persons are by definition havana, friends and fictive or real kin, while a stranger will never be trusted at all. But how do envy and the underlying tension emerge between socially close people?

Paul, aged twenty-two, a student of natural sciences, once confirmed to me the prominent narrative that it is a close friend who will envy you most and who might do you harm. His illustration of the evolution of envy was very clear - and unwittingly hinted that everybody not only fears the other's envy but envies others too.

Envy starts if you have a friend and he becomes too close. Envy would grow when people are close and start to know more and more about the other. I know that I could love my friend only until a certain point. Sometimes I might be too close ... And sometimes I think he is boasting or became stupid [when he displays something that Paul doesn't have]. But then I would also see what the other has, what he has got. And then I start to become curious and 'count the money in his pocket'. Then I will ask myself: how come that he has something that I do not have? And that is why we say, if you like your friend, you have to keep your distance.

As is common in Malagasy discourse, Paul's narrative contains implicit comments that need to be elaborated and contextualized. Paul illustrates how social closeness, reciprocity and mutual love can easily - maybe even inevitably - turn into suspicion when a former relationship based on trust and equal status changes into one of mistrust and inequality. The basis of friendship is that friends should share not only knowledge but also any achievements. Yet, Paul implicitly referred to an accomplishment that his friend did not communicate to him. The turning point came when his friend started to display his success in a manner that was interpreted as inappropriate, here in a boasting manner. Paul did not know how the other man could have achieved success without letting it be known and sharing that success. The gap in knowledge results in inappropriate 
curiosity, as shown by the common phrase 'counting the money in people's pockets' (manisa vola an-paosin'olona). This kind of curiosity is often seen as a sign of envy. At this point, Paul explained that people become more careful and try to distance themselves from their friends. However, this is not so easy to do in close relationships since the envious party might see it as proof that the envied person is unwilling to share. They would then envy them more, and since the growing resentment would be unspoken, the tension would not be resolved. Again, this is a vicious circle.

The question of appropriate and inappropriate display is another theme that runs through most narratives of envy. These stories are often gendered, with both goods and violence playing a bigger role in men's narratives. Casimir once explained:

Here, envy is so present. With boys, it is obvious. If someone owns a tablet or an iPhone then he is well off. That will attract other people. The girls prefer such trendy guys. And boys will search out his friendship. He will have a lot of 'friends'. They will be very nice but they feel different [hiding their intentions]! They will wait for the perfect moment and then they will send other people to attack him. They will tell these guys that he is showing off too much with all the stuff that he has. They will beat him up and maybe take his stuff.

Boys have to compete for women, and those who are well off have the chance to impress and attract others. The flip side of possessions is the possibility of 'showing off' (werawera), in which admiration turns into hostility and violence. Men are likely to be in more danger of attracting others' envy as they have to 'show off' at a certain point, for example to seduce women or to get a better position. At the same time, not talking too much and being modest (tsotra) rather than boasting are aspects of masculinity in Madagascar. Young women similarly compete with other girls, and their narratives contain similar topics of betrayal; however, they are less concerned with technological goods, physical violence and destruction. If girls talk about envy, they talk about how their family was or is envied, and about hidden intentions in their everyday life, for example in study groups. If young women compete with other girls they do it through clothes and hairstyles, while the most prestigious achievement would be a relationship with a young and good-looking European man.

Young people in Mahajanga usually try to find a middle way that balances social proximity and distance. The goal is not to attract attention through ostentatious display or bragging. As explained by Henri, a law and political science student: 'You try to do what others do in social life. But at the same time, you try to keep as much distance as possible to avoid others' feelings of envy. You need to build secrecy around your life.'

Secrecy and disclosure have long been subject to anthropological scrutiny (see Jones 2014; Manderson et al. 2015) and they are essential elements in envy narratives. They are projected onto the supposed envier and manifest themselves in the way in which hidden intentions are blamed and in the fact that the envied person feels the need to shield him- or herself from the curiosity of others and the threat they pose to individual endeavours. Secrecy and the concealment of information are instrumental and exclusionary but similarly sustain important and intimate relationships, usually among the family or the household. They are a protective device to avoid social pressure and regulation (Simmel 1906) and to provide the power to control social interactions (Wolf 1990), in this case by controlling the 
moment when the secret or knowledge is revealed to those who were previously excluded. Secrets can be maintained, firstly, through communicative practices of silence and revelation (Bellman 1984), and secondly by material practices (Archambault 2013).

Young Mahajangais put a lot of effort into managing information and sharing it selectively with others. In particular, young men generally resort to silence when confronted with the curiosity of others. Henri continued:

If you remain silent, you have less problems. Even if others would understand it as arrogance. But you do so because of the curiosity of others. They want to know. And the more they know the more trouble you have. If they don't know anything about us, they get angry. Because they want to know and then they will tell anybody that we are evil and arrogant. Now they gossip, but if they would know about us, it would be worse than gossiping. They would know the bad and good sides about us. And if they would know they would cut off everything.

Henri called on a discourse of envy that trapped his family and neighbours. He knew that silence and concealment, even denial, would increase the curiosity of his neighbours and therefore their resentment. Still, he perceived the accusations of arrogance as a lesser evil when compared with his family revealing itself. 'To cut off' or 'block' (mandradra homana; literally 'to forbid [someone] to access food') is a common expression in Malagasy that describes practices of obstructing others' endeavours by gossiping or even through violence. When I asked him about this dynamic of making others more curious through practices of secrecy, he answered:

Yes, but it is difficult to measure. People here are turning and don't speak frankly. They don't say what they really mean. They are hiding [their intentions] ... So if they don't do it, I am not frank either.

The desire to shield oneself from the curiosity of others could also be expressed physically. After an unsuccessful lawsuit against her neighbours, Karin, aged twenty-two and a female student, told me about her future dreams and hopes. I knew that she was planning to migrate to France and expected her to express her hope of obtaining a visa or that her related financial problems would be solved. Yet, to my surprise, she answered that she wished she had the money to construct a wall around her family's compound. She meant a solid wall built of stone, not the broken wooden fence that enabled outsiders to gaze in and even to enter the compound easily. Karin's desire to shut out the gaze of neighbours and passers-by is reflected in the common Malagasy expression tokatrano tsy ahahaka, 'the house is not to be exposed'. Nothing should escape from the intimate life of families and nothing from outside should enter. The house is literally a place of retreat and security, and the members of the household are the people who are most trusted. ${ }^{7}$ Shielding oneself from the gaze of others (using a wall) - or more generally from their curiosity - is one of the many forms of boundary work that has its

\footnotetext{
${ }^{7}$ Although this is relative. The family is not necessarily the cradle of trust, but most people see their household members as more trustworthy than others.
} 
roots in the desire to be middle class as well as in the discourse of envy. Anxieties are similarly rooted in middle-class subjectivities as well as in envy narratives.

The most important element of secrecy is control of the environment of concealment and disclosure. Secrets entail the possibility of being shared and are resources for interaction. Yet, it is not the content of the secret that is important here. Everybody in Mahajanga suspects that others try to gain prestige and status through goods, migration or professional occupations, and therefore secret individual projects are not secret at all, although they are not easily expressed. Rather more important is whether, how and when the secret is going to be disclosed. The failure of individual or family projects should not be revealed, because their failure is considered shameful. Successes, on the other hand, should be disclosed at the moment chosen by the individuals concerned. Failure and success are therefore at issue in envy-related social practices and in discourses on concealment and display.

\section{Fear of failure and the sweetness of success}

The fact that students have an elevated status does not make their anxieties any less real, yet they have to be contextualized. All Mahajangais define envy as a deep negative emotional experience that arises in situations where others desire someone's possessions, be they objects, advantages or superior status. The desire, or its perception, leads to resentment, hostility and finally violence. The 'other' is the main aggressor, and his envy is feared. At the same time, these perceptions are rarely based on violent experiences but mostly express suspicion about the hidden intentions of the other. I argue that the fear of others' envy is not related to the fear of violence nor to the loss of possessions, but to a fear of failure and the resulting public humiliation.

Although 'fear of others' envy' is a common expression, it would be more accurate to speak of anxieties or worries. While fear is related to existential and precarious situations of war, torture or natural catastrophes, the anxieties that are related to envy are mainly expectations of an unpredictable situation that might involve violence but does not necessarily do so. What are these students afraid of, that makes them express their need for social distance? If narratives of aspiration are tinged with others' envy, they focus on the fear that their projects will fail. In other cases, they relate to an aggressive individual who will strip people of their goods, or stories about the fate of a family that will lose the little it has achieved because of a neighbour's envy.

One of the most common complaints of other people is that they 'block' any individual endeavours. Practices of 'cutting off' or 'blocking' (mandradra homana) are considered to be secret and untraceable and obstruct an individual's path to success. Being 'blocked' by other people happens through gossip and slander rather than through open violence. This corresponds to the general attitude that envy is not necessarily a threat to the social order, but to an individual's social mobility.

The only time I heard reports of death was when Luc recalled that his elder brother had died in 2009 when he was thirty-seven years old. He had a knee problem and limped but was very successful as a director of finance in a company based in Analalava. He died from poison because he was envied. He was out drinking and when he went to the toilet, his friends put something in his drink. 
Again, this narrative reveals the social closeness of those who finally betrayed Luc's brother and carried out an attack using poison. Poison and its ingestion are deeply entrenched in the social life of Madagascar through 'medicine' (fanaf$o d y$ ) that can be used in both a positive and a negative way. Maurice Bloch has argued that the consumption of food cooked from one hearth implies unity and that 'concepts of kinship and commensality act together and are often believed to imply one another' (Bloch 1999: 139). Sharing food, family and trust are therefore mutually constitutive, while non-family are generally the other that has to be mistrusted, and one of the imagined dangers is poisoning. Young people in Mahajanga are constantly afraid that someone might secretly mix food or drink with love magic (aody fitia), the consequence of which is that one loses one's free will. On other occasions, I heard that young students who worked with foreign NGOs in the city's countryside refused invitations to eat in villages because they were anxious about poisoning. Throughout the nineteenth century, ordeals by poison (tangena) were common in the Merina empire; they were ordered by the elites against witches, but also against slaves, servants and insubordinate rivals or villages (Campbell 1991; Ellis 2002).

Although several scholars refer to the metaphysical evil personified in the figure of the witch, young people in Mahajanga rarely mentioned witchcraft as the root of aggression. Acts of poisoning and defamation are both attributed to people, not witches. ${ }^{8}$ Gossip that turns from normal chatter to harmful slander is considered to be the main weapon - and a powerful one - against any scheme that might lead to a better life.

If there is a possibility of achieving a status in the future that is superior to that of people who were formerly close, this can attract potential harm from others. However, one's anxieties - coupled with imagination - do not necessarily relate to the acts of aggression one might face, but rather to the possibilities of a project failing. Of course, a breach through violence and the fear that someone else could take one's possessions are terrifying. But more terrifying is the loss of status, the resulting humiliation and the fear that others might look down on you and laugh at you if you were to fail and lose your status. ${ }^{9}$

\footnotetext{
${ }^{8}$ The role of witchcraft in urban Mahajanga is an interesting and important topic. Since it is not immediately embedded in articulated envy discourses, I do not provide a detailed account here. Still, it is worth mentioning that, like envy, witchcraft - as well as many aspects of the occult is part of a semantic field that is unspoken. But unlike the unspoken aspect of envy, which is related to norms of conflict avoidance, witchcraft is not mentioned because of the religious dominance of Christianity and other religions. Although most believe in witches, the ancestors and all sorts of spirits, they prefer to appear as a 'true Christian' in public, and thus as someone who has left the occult of Malagasy culture behind. I believe that belief in the occult is still common but it is not - or is rarely - articulated. Many people felt uncomfortable when I tried to discuss the subject, yet some commented on witchcraft in opaque sub-clauses.

${ }^{9}$ The anxieties of failure reflect similar findings on everyday hardship, poverty and neoliberal pressure described in Cole's ethnography. She described the sadness (malahelo) that also connotes bitterness and resentment when young people feel humiliated and mistreated due to their lack of material resources and possibilities (Cole 2010: 47). The term malahelo, however, is not very common among students in Mahajanga. I suspect that their elevated status makes them resistant to the feeling, but it might persist as fear. Instead, I sometimes heard the term alahelo (grief, sorrow), an emotion that appears if a child is disobedient towards the parents and makes them grieve. The result would be guilt (tsiny) on the part of the child.
} 
Alongside the possibility of betrayal, the stigma of shame through status loss is frightening. Together, these are considered the worst humiliations that one can endure. The prospect of possible poverty and the attached stigma is what terrifies most young educated urbanites. And yet, these young Mahajangais do not consider envy to be a problem that will pass. It is so deeply rooted in the social fabric that one has to avoid it, circumvent it, and sometimes even appreciate it. Like any fear, it must be overcome. For some young people, envy has been a sign of appreciation of their efforts. Yolande, aged twenty-one, a young law student, illustrated this point:

We think that if nobody envies you, you really should think about your fate and ask yourself question[s] because there is something really wrong. Otherwise, envy is more or less a factor which completes the life of someone [in general]. To be somebody you should be envied and not envying. When older people bless you, they will say 'Be that people will envy you and not that you will envy them.'10

The important point here is that envy is part of everyday life. Although it might be perceived as having destructive components, people in Mahajanga know that it is unavoidable, a challenge everybody has to face and to cope with. But it is even more, as Yolande argues: it is something that makes one's life 'complete' in the sense that it is satisfying. Although in general envy is regarded as a morally negative emotion, being envied means being on the right track. It is something productive that keeps people alive. Envy discourses can push young people forward, not necessarily by entering the rather new paths of social mobility through the growing sex economy, as described by Cole, but rather by treading the old paths of higher education and the dream of the civil service or migration.

The fear of envy, therefore, does not lead to a gloomy zero-sum game, nor does it necessarily amplify social inequality. Envy does not shape social behaviour or act as a social regulator. Young people in Mahajanga may deny or conceal many activities, but their fear of others' envy does not stop them from gaining status and prestige. It is not that fear discourages innovation, effort and achievement. It does not stifle creativity and aspiration. People are well aware that any success they achieve, any goods they acquire and any position they occupy will sooner or later be part of local gossip and envy, and thus it is inevitable that one has to shield oneself from this. More important is the way in which individuals and their families display success, be it in a provocative manner of conspicuous consumption, or in a socially accepted and modest way.

\section{Envy as a marker of ambivalent (mis)trust}

Without undermining the problematic nature of envy for most individuals in Mahajanga, I take a critical view of some of the narratives and practices of

\footnotetext{
${ }^{10}$ Mba hirin'olona fa tsy haniry olona. This passage was transcribed from an interview conducted in English. Cole translated the common proverb correctly as "may you be desired by others but may you not desire others' (Cole 2010: 59). However, since Yolande used 'envy' instead of 'desire', I left it as articulated.
} 
young men and women. In his comment on the extensively quoted article on envy by Foster, the anthropologist Jan Christian Brøgger noted that:

almost any human symbolic act may with some skill be reduced to disguise envy, in the same way as a psychoanalytical zealot may reduce almost everything to repressed sex ... symbolic expressions often are overdetermined, like dream-symbols, they have more than one referent. (Brøgger in Foster 1972: 188)

Taking this remark into account, one could ask whether accusations of envy, hidden intentions and the related practices of concealment, silence, denial or secrecy are expressions of different phenomena that are related to a local code of conduct or reflect a different vision of an individual's future. For example, the avoidance of bragging to deflect others' envy could also be seen as avoidance of shaming others who are less fortunate, something that would be considered moderate (tsotra), a virtue that is highly valued in Mahajanga. The wish of a young student to build a concrete wall around her house could likewise be understood as a general aspiration of middle-class families who admire the secure compounds of richer families in the more highly valued quarters of the city. Indeed, envy discourses are informed by and inform many different aspects of social life. It becomes difficult to draw a line where envy starts and where it ends, and therefore it is problematic to posit envy as a universal aspect of social life. If envy discourses primarily emphasize anxieties of failure and humiliation, aspirations and middle classness, while mirroring the transformation of trust into mistrust and suspicion, then envy might not be useful as an analytical concept but as a frame that brings together dissimilar aspects of everyday life. If we do not take envy for granted but focus on the anxieties of close relations, hidden intentions and practices that promote concealment, we clearly reach beyond the common constructive-destructive division that dominates anthropological perspectives on envy. If mistrust and suspicion are the central terms, then envy is merely a moral category that signifies unsocial behaviour.

In contrast to recent studies that link mistrust to the breakdown of law and order (Gade et al. 2015), historical circumstances such as the slave trade (Nunn and Wantchekon 2011) or ethnic diversity (Robinson 2013), the urban context of Mahajanga represents a rather moderate environment that may even be slightly better off than other cities when it comes to security, well-being and employment. Mistrust in the coastal city is related to the knowledge gaps of everyday situations. It becomes a powerful discourse within the context of migratory or any other life projects. The uncertainty of knowing whether people will act according to their own interests or meet the obligations that are implied in socially close relations generates mistrust and suspicion. Ideally, people should help one another, but the realities of the job market, rising prices and the tight migration market force them to be secretive and competitive. Again, envy is the prime reflection of this: a person who feels that they are the target of envy might not know exactly who the envier is or what they are envious of, although they will inevitably speculate on this. Uncertain about others' intentions, social actors feel forced to change their behaviour towards others by acting more covertly or by being modest in order to downplay their status. The social distance produced, however, will arouse suspicion in those who are accused of envy. If someone conducts their business in secret and displays their achievements only in the moment 
of their success, others will be suspicious about how they achieved that success and are likely to turn to explanations that frame the other person's success with reference to perceived immoral and unjust practices such as corruption or nepotism. These unspoken accusations will arise and increase suspicion in the person who already suspected envy, thereby closing the vicious circle of mutual mistrust.

The power of this mistrust is rooted in the many unsaid moments of everyday life that leave tensions unresolved. Talk is mostly indirect. The use of language is an art one has to learn; it is a sign of adolescence to know how to talk but also how to be able to read between the lines of what others say. To speak out loud and directly is considered inappropriate behaviour. Instead, practices of politeness, face-saving and showing respect to others are commonly expected from adults and adolescents. Many aspects of public life are about having or not having good manners, about respect and disrespect, as well as about being categorized by others as modest (tsotra) or proud (mihavona). The expected norm would be to link one's individual destiny (anjara) to the destinies of one's fellow human beings - family, friends, neighbours and strangers. Conflicts, on the other hand, mostly involve accusations of being disrespectful, and techniques of conflict avoidance are highly valued (for Madagascar in general, see Dahl 1999; Keenan 1974). ${ }^{11}$

If people maintain social distance because of their fear of envy, as long as they do not voice their accusations, then norms of social cohesion hold steady. However, the gap between a dominant normative and moral discourse and an underlying current of social tension as expressed in envy discourses is not 'unbridgeable'. At the same time, young men and women in Mahajanga cannot rely exclusively on their intimate family or members of the household as trustful companions. To achieve a better life, a wider social network is necessary - and this involves people who are feared because they can betray and harm those who are successful. Communicative-emotional bonding is of utmost importance beyond its utilitarian aspect. Thus, envy might be overexposed in everyday life, and yet it is not everywhere; rather, it appears in certain contexts. Initial mistrust might indeed be 'half-trust' (Gade et al. 2015), while envy and 'mutual love' might be more intertwined than it initially appears in narratives of young educated urbanites.

\section{Conclusion}

In his account on Betafo, David Graeber criticizes the existing literature on envy. He argues that authors have made envy appear in isolation without considering the actions of those who are the target. Instead of focusing on wealth and property, Graeber claims, one should take a closer look at displays of wealth and sexual rivalry, since envy is produced by the desire of wealthy people to be envied. Instead of being a product of egalitarianism, envy is the 'driving force behind the desire to accumulate and to establish hierarchies that threatened to break

\footnotetext{
${ }^{11}$ During my fieldwork, I rarely observed open conflicts on the street or in public establishments. Couples who were fighting were looked down upon, and when a fight between two groups of women broke out in a café - again about respect and disrespect - others came to help at a certain point. Only twice did I see a violent fight between men.
} 
egalitarian communities apart' (Graeber 2007: 86). His point is that a grounded sympathy to each other could easily reverse and become destructive.

In this article, I have taken the perspective of the 'superior' people whom Graeber criticized: namely, students and graduates from middle-class backgrounds. This focus evolved out of a methodological problem that nobody would admit to envying others. As a prism into the micro-politics of the unsaid, hidden accusations, experiences of betrayal and the shame of failure, however, envy has been extremely useful to understand the ambitions and aspirations of youth as well as the perception of constrains, anxieties and questions of closeness and distance in urban sociality.

The interrelatedness of aspirations and anxieties has been most prominently anchored in middle-class milieus, where strivers and strugglers constantly engage in the dynamics of status and social competition. However, envy in Mahajanga is not as destructive as Graeber observed in the Central Highlands of Madagascar. According to my observations among students and graduates, neither witchcraft nor sexual seduction has been used and cases of poisoning have been rare. Instead, the structural violence of gossip and slander has been prominently articulated as the most powerful instrument that could bring someone down. Mahajangais tend to be gripped by the expectations of others' envy, not necessarily the experience of it. The struggle to justify their aspirations to others, mostly close companions, leaves them with a moral dilemma - and maybe even an inherent guilt - about balancing their relationships between individualism and collective obligations.

At first glance, envy and its related features of mistrust, enmity and suspicion point towards the opposite of any closeness symbolized by the Malagasy concepts of havana and fihavanana. Yet, the dissonance between the openly articulated norms of harmonious social togetherness and the tacit social undercurrent of envy is not as incompatible as it seems. As long as envy echoes an often ongoing tension that has not broken out into open conflict, no norm has been breached. Moreover, the polite behaviour that could be interpreted as social dissociation confirms conflict-avoidance practices.

Rather than asking if fihavanana exists or not, one should analyse when trust flips into mistrust and vice versa. How and when do people cooperate, share and pull together? And in which situations do they refrain from being havana, kin, with the obligations of sharing and solidarity? The general tension between individual ambitions and being solidary, between inequalities and social cohesion, is one of the main dynamics that drives youth in Mahajanga into navigating social distance and proximity. Shall we cooperate and be solidary with our neighbours based on being close spatially and being Malagasy, although we come from different cultural backgrounds and economic strata and live different lives? Or will someone distance him- or herself from any social interaction with others, following their individual aspiration but at the same time being perceived as arrogant, with the result that they are envied and possibly assaulted in the future because of it?

Like so many earlier attempts, the plan of Luc, who wanted to seduce a US tourist and marry her to get the desired papers, failed. When I left Madagascar, he was still struggling to find a way out, but he promised to keep me informed about his future. We stayed connected through Facebook and WhatsApp, and after a year he suddenly revealed to me that he was coming to Europe. At first, I just dismissed his short SMS as another of his unsuccessful ideas, so I was 
surprised when he suddenly mailed me from coastal Italy. It seemed that he had married a Malagasy woman with Italian citizenship. Shortly thereafter, he started to regularly post photographs on Facebook of himself in a suit in front of a flat-screen TV and stereo system, sitting in a new car or on a train, or posing with Italian children or with a beautiful woman. These practices of bragging infuse and increase envy in those who are left behind. However, since Luc successfully navigated the constraints of envy and seemingly overcame the struggles related to migration, envy is coupled with admiration and awe. Comments on his pictures, for example, were tinged with praise: for example, 'Everybody knew that Luc would make it.' Envy, in fact, mirrors the strong ambivalence of resentment and respect, distance and closeness, equality and inequality, as well as concealment and revelation.

\section{References}

Andriamitantsoa, T. H. (2009) 'Une métropole régionale dans un pays en voie de développement: Majunga'. PhD thesis, University of Antananarivo and Université Blaise Pascal Clermont Ferrand II.

Archambault, J. S. (2013) 'Cruising through uncertainty: cell phones and the politics of display and disguise in Inhambane, Mozambique', American Ethnologist 40 (1): 88-101.

Ballarin, M.-P. (2006) 'Culte des ancêtres royaux et légitimation du pouvoir dans la région de Majunga (nord-ouest de Madagascar), 1822-2004', Journal des Anthropologues 1 (104-105): 191-217.

Behrends, A. and C. Lentz (2012) 'Education, careers, and home ties; the ethnography of an emerging middle class from northern Ghana', Zeitschrift für Ethnologie 137 (2): 139-64.

Bellman, B. L. (1984) The Language of Secrecy: symbols and metaphors in Poro ritual. New Brunswick NJ: Rutgers University Press.

Bloch, M. (1971) Placing the Dead: tombs, ancestral villages, and kinship organization in Madagascar. London: Seminar Press.

Bloch, M. (1999) 'Commensality and poisoning', Social Research 66 (1): 133-49.

Campbell, G. (1991) 'The state and pre-colonial demographic history: the case of nineteenth-century Madagascar', Journal of African History 32 (3): 415-45.

Castellanos, D. M. (2013) 'Locations of envy: an ethnography of Aguabuena potters'. PhD thesis, University of St Andrews.

Clanton, G. (2006) 'Jealousy and envy' in J. E. Stets and J. H. Turner (eds), Handbook of the Sociology of Emotions. New York NY: Springer.

Cohen-Charash, Y. and E. Larson (2017) 'What is the nature of envy?' in R. H. Smith, U. Merlone and M. K. Duffy (eds), Envy at Work and in Organizations. Oxford: Oxford University Press.

Cole, J. (2001) Forget Colonialism?: sacrifice and the art of memory in Madagascar. Berkeley CA: University of California Press.

Cole, J. (2010) Sex and Salvation: imagining the future in Madagascar. Chicago IL: University of Chicago Press.

Cole, J. (2014) 'Producing value among Malagasy marriage migrants in France: managing horizons of expectation', Current Anthropology 55 (9): 85-94. 
Dahl, Ø. (1999) Meanings in Madagascar: cases of intercultural communication. Westport CT: Bergin and Garvey.

Danielli, M. (1947) 'The witches of Madagascar: a theory of the function of witches and of their organization based on observations of an existing cult', Folklore 58 (2): 261-76.

de Vidas, A. A. (2007) 'The symbolic and ethnic aspects of envy among a Teenek community (Mexico)', Journal of Anthropological Research 63 (2): 215-37.

Dez, J. (1981) 'L'illusion de la non-violence dans la société traditionnelle malgache', Droit et Cultures 2: 21-44.

Ellis, S. (2002) 'Witch-hunting in central Madagascar 1828-1861', Past and Present 175 (1): 90-123.

Evans-Pritchard, E. E. (1976 [1937]) Witchcraft, Oracles, and Magic among the Azande. Oxford: Clarendon.

Festinger, L. (1954) 'A theory of social comparison processes', Human Relations 7 (2): $117-40$.

Foster, G. M. (1972) 'The anatomy of envy: a study in symbolic behavior', Current Anthropology 13 (2): 165-202.

Freeman, L. (2013) 'Speech, silence, and slave descent in highland Madagascar', Journal of the Royal Anthropological Institute 19 (3): 600-17.

Gade, C. B., R. Willerslev and L. Meinert (2015) "'Half-trust" and enmity in Ikland, Northern Uganda', Common Knowledge 21 (3): 406-19.

Geschiere, P. (2003) 'Witchcraft as the dark side of kinship: dilemmas of social security in new contexts', Etnofoor 16 (1): 43-61.

Graeber, D. (2007) Lost People: magic and the legacy of slavery in Madagascar. Bloomington IN: Indiana University Press.

Gueunier, N. J. (1975) 'Le thème de la sorcellerie maléfique dans la littérature populaire écrite à Madagascar', ASEMI 6 (1): 71-84.

Hardyman, J. T. (1974) 'Observations sur la sorcellerie "Ambalavelona" dans la région de l'Antsihanaka', Bulletin de l'Académie Malgache 52 (1-2): 57-63.

Hicks, R. G. (2013) 'The politics of envy: progress, corruption, and ethical kinship among Bolivian immigrants in Escobar, Argentina'. PhD thesis, University of Michigan.

Jones, G. M. (2014) 'Secrecy', Annual Review of Anthropology 43: 53-69.

Keenan, E. (1974) 'Norm-makers, norm-breakers: uses of speech by men and women in a Malagasy community' in R. Bauman and J. Sherzer (eds), Explorations in the Ethnography of Speaking. Cambridge: Cambridge University Press.

Kneitz, P. (2014a) 'Introduction: la paix du fihavanana' in P. Kneitz (ed.), Fihavanana: la vision d'une société paisable à Madagascar. Halle: Universitätsverlag HalleWittenberg.

Kneitz, P. (ed.) (2014b) Fihavanana: la vision d'une société paisible à Madagascar. Perspectives anthropologiques, historiques et socio-économiques. Halle: Universitätsverlag Halle-Wittenberg.

Kracker Selzer, A. and P. Heller (2010) 'The spatial dynamics of middle-class formation in postapartheid South Africa: enclavization and fragmentation in Johannesburg', Political Power and Social Theory 21: 171-208.

Lambek, M. (2003) The Weight of the Past: living with history in Mahajanga, Madagascar. New York NY: Palgrave Macmillan.

Lentz, C. (2015) Elites or middle classes? Lessons from transnational research for the study of social stratification in Africa. Working Paper 161. Mainz: 
Department of Anthropology and African Studies, Johannes GutenbergUniversität.

Manderson, L., M. Davis, C. Colwell and T. Ahlin (2015) 'On secrecy, disclosure, the public, and the private in anthropology', Current Anthropology 56 (S12): $183-90$.

Mercer, C. (2014) 'Middle-class construction: domestic architecture, aesthetics and anxieties in Tanzania', Journal of Modern African Studies 52 (2): 227-50.

Njara, E. (1992) 'Le fihavanana', Droit et Cultures 24: 152-9.

Nunn, N. and L. Wantchekon (2011) 'The slave trade and the origins of mistrust in Africa', American Economic Review 101 (7): 3221-52.

Ottino, P. (1998) Les champs de l'ancestralité à Madagascar: parenté, alliance et patrimoine. Paris: Karthala.

Razafindrakoto, M., F. Roubaud and J.-M. Wachsberger (2015) 'The puzzle of structural fragility in Madagascar: a political economy approach'. Berkeley CA: Center for Effective Global Action, University of California <http://cega.berkeley.edu/assets/miscellaneous_files/79_-ABCDA_2015___Madagascar_Structural_ Fragility.pdf>, accessed 16 January 2018.

Robinson, A. L. (2013) 'Ethnic diversity, segregation, and ethnocentric trust in Africa'. Working Paper 166. N.p.: Afrobarometer <http://afrobarometer.org/ publications/wp166-ethnic-diversity-segregation-and-ethnocentric-trust-africa $>$, accessed 22 January 2018.

Sandron, F. (2008) 'Le fihavanana à Madagascar: lien social et économique des communautés rurales', Revue Tiers Monde 3: 507-22.

Savage, M., G. Bagnall and B. Longhurst (2001) 'Ordinary, ambivalent and defensive: class identities in the northwest of England', Sociology 35 (4): 875-92.

Schoeck, H. (1969) Envy. London: Secker and Warburg.

Sharp, L. A. (1996) The Possessed and the Dispossessed: spirits, identity, and power in a Madagascar migrant town. Berkeley CA: University of California Press.

Sharp, L. A. (2002) The Sacrificed Generation: youth, history, and the colonized mind in Madagascar. Berkeley CA: University of California Press.

Simmel, G. (1906) 'The sociology of secrecy and of secret societies', American Journal of Sociology 11 (4): 441-98.

Southall, R. (2004) 'Political change and the black middle class in democratic South Africa', Canadian Journal of African Studies 38 (3): 521-42.

Spronk, R. (2012) Ambiguous Pleasures: sexuality and middle-class self-perceptions in Nairobi. Oxford: Berghahn Books.

Sumich, J. (2015) 'The uncertainty of prosperity: dependence and the politics of middle-class privilege in Maputo', Ethnos 81 (5): 1-21.

Taggart, J. M. (2012) 'Interpreting the Nahuat dialogue on the envious dead with Jerome Bruner's theory of narrative', Ethos 40 (4): 411-30.

Tapias, M. and X. Escandell (2011) 'Not in the eyes of the beholder: envy among Bolivian migrants in Spain', International Migration 49 (6): 74-94.

Wallner, I. (2016) 'Fihavanana: exchange, social cohesion and social exclusion in Madagascar' in L. Prager, M. Prager and G. Sprenger (eds), Parts and Wholes: essays on social morphology, cosmology, and exchange in honour of J. D. M. Platenkamp. Zurich: LIT.

West, M. O. (2002) The Rise of an African Middle Class: colonial Zimbabwe, 1898-1965. Bloomington IN: Indiana University Press. 
Wolf, E. R. (1955) 'Types of Latin American peasantry: a preliminary discussion', American Anthropologist 57: 452-70.

Wolf, E. R. (1990) 'Distinguished lecture: facing power - old insights, new questions', American Anthropologist 92 (3): 586-96.

\begin{abstract}
In this article, I examine the fear of others' envy among young students and graduates in the port city of Mahajanga, Madagascar. Although the city provides a favourable environment in relation to the economy, employment and general well-being, many young people from middle-class milieus worry that their aspirations will remain unfulfilled because of envious peers who resent them for any advantage they might have gained. While malicious envy is most expected within close social relations in which social comparison and competition are prevalent, most social actors respond to this threat with tactical practices of secrecy that arguably help to secure an individual's well-being and shield them from unsocial behaviour. I scrutinize these micro-politics of life projects, social comparison, increasing inequalities and a rising sense of mutual mistrust. Yet, I depart from approaches that frame envy as a human condition that socially produces either a prosocial levelling mechanism or a destructive force that bulldozes social bonds. Instead, I understand envy as an assemblage that points to intertwined and often ambivalent social aspects. For many young individuals, overcoming their fear of envy is part of becoming a complete person, a sign of being successful and a responsible adult.
\end{abstract}

\title{
Résumé
}

Dans cet article, l'auteur examine la peur de l'envie des autres parmi les jeunes étudiants et diplômés de la ville portuaire de Mahajanga (Madagascar). Bien que la ville offre un environnement favorable pour ce qui est de l'économie, de l'emploi et du bien-être général, de nombreux jeunes issus des classes moyennes craignent que leurs aspirations ne demeurent inassouvies parce que des pairs envieux leur en veulent d'avoir profité d'avantages. L'envie malveillante ne saurait surprendre dans le cadre de rapports sociaux étroits dans lesquels la comparaison sociale et la concurrence sont prévalentes, mais la plupart des acteurs sociaux répondent à cette menace par des pratiques tactiques de secret qui aident sans doute à assurer le bien-être d'un individu et à le protéger des comportements asociaux. L'auteur examine ces micropolitiques de projets de vie, de comparaison sociale, d'inégalités grandissantes et de sentiment croissant de méfiance mutuelle. Cependant, il s'écarte des approches qui cadrent l'envie comme une condition humaine qui produit socialement soit un mécanisme de nivellement prosocial, soit une force destructrice qui piétine les liens sociaux. Au lieu de cela, il interprète l'envie comme un assemblage laissant entrevoir des aspects sociaux imbriqués et souvent ambivalents. Pour beaucoup de jeunes, surmonter la peur de l'envie fait partie de l'achèvement personnel, un signe de réussite et de statut d'adulte responsable. 